\title{
Planning centres - new conception for re-engineering activities in non-producing areas
}

\author{
M. Remme, A.-W. Scheer
}

Institut für Wirtschaftsinformatik IWi (Institute for Information Systems) at the University of the Saarland, Im Stadtwald, Geb. 14.1, 66123 Saarbrücken, Germany

Tel.: +49/681/302-4297, Fax: +49/681/302-3696

E-Mail: remi@iwi.uni-sb.de

\begin{abstract}
The definition of tasks and functions as well as their relationships is one of the main tasks of organising an enterprise. Usually, this is done step by step. This means the complexity of an enterprise's overall task is broken down. The resulting subtasks must be assigned to individual task performers. Only if the task is adequately broken down, task performers will be able to execute it properly. Starting from present-day requirements, this paper explains fundamental organisational patterns to reduce the complexity in enterprises. As point of departure these patterns are used to derive the conception of planning centres. Afterwards, the way down to planning centres-i.e. the enterprise's re-engineering - is lined out and experiences gained in an industrial project are explained.
\end{abstract}

\section{Keywords}

Planning centre, business process re-engineering, complexity of organisational structures, functional-, object-oriented and hybrid paradigm for organising enterprises, networked decentralisation, Architecture of Integrated Information Systems (ARIS), re-usability of organisational knowledge.

\section{INTRODUCTION}

Over the last decades major improvements in technology and personnel's qualification have effected that those who take advantage of this development in re-designing their organisa- 
tional structures meet the competition of the market. Catchwords like lean production, decentralisation, business process re-engineering etc. represent paradigms of how to adapt the enterprises to these new challenges.

Four industrial companies assisted by five research institutes and consultancies are investigating the conception of the planning centres which represent the missing component to complete current decentralised and process-oriented approaches to an overall flexible and customer-oriented enterprise organisation called networked decentralisation (Scheer 1994, p.585). Figure 1 illustrates the structure of the project "Funktionsintegration in Planungsinseln" (Integration of functions in planning centres) which is funded by the German Ministry for Education, Science, Research and Technology (BMBF). It defines an architecture of decentralised organisational units in non-producing areas of enterprises and how this architecture is applied. There are four autonomous partial projects which in each case consist of one industrial company and one or two supporting partners. All the partial projects have to implement a pilot planning centre but they differ in the main functionality of the planning centre and in the enterprise-specific preconditions. While e.g. fischerwerke manufactures dowels in mass production Fortschritt manufactures machines for harvesting in small serials. The project is co-ordinated by the Institut für Wirtschaftsinformatik IWi (Institute for Information Systems), which thus, has a double-function beside being a supporting partner.

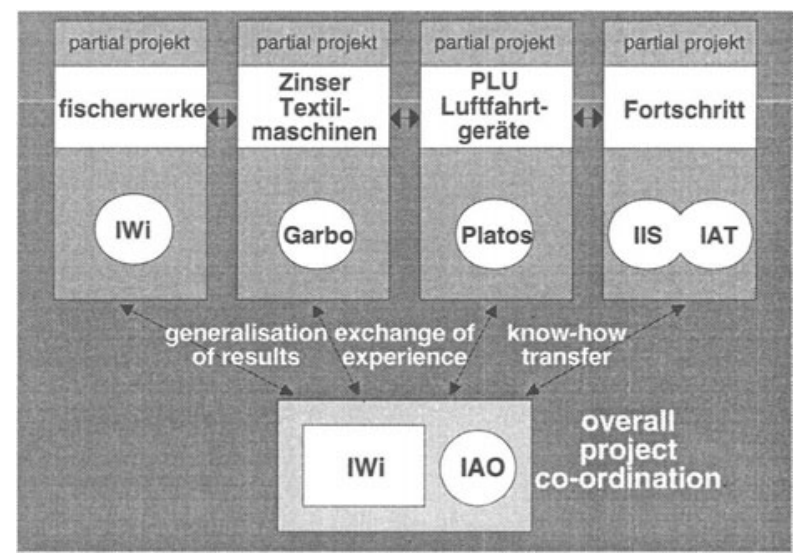

Figure 1 Structure of project referred to.

\section{BREAKING DOWN THE COMPLEXITY OF ORGAN- ISATIONAL STRUCTURES}

In industrial organisations, when a problem's complexity is defined by the effort a human being has to expend in order to solve it, this complexity is the result of the multitude of functions to be processed and the large number of goods and services to be scheduled (materials, 
component parts, assemblies, all the way to end products). (Grossmann 1992, pp.18, Flood/Jackson 1991, pp.33) Figure 2 compares these two dimensions, with the size of the area representing the overall complexity. (Scheer 1994, p.7)

Dividing this complexity area into individual sections serves to reduce the overall complexity. The predominant form of structuring is function-oriented. In a functional structure, one organisational unit (e.g. staff, department) is given responsibility for all areas and products. This principle is illustrated in Figure 2 by horizontal lines. This approach takes advantage of specialisation effects of the employees. A disadvantage of a highly departmentalised functional structure is the high communication and co-ordination effort. Transferring data between all these departments causes high transferring, waiting and working-in times.

Since this structural principle was the prevailing organisational form in the early days of electronic data processing, DP structures reflect horizontal compartmentalisation schemes. Usually, these function-oriented information systems contain their own databases, as illustrated in Figure 2. A closer look, however, shows that these business functions are linked by decision and process relationships: When objects (or outputs) are processed, they typically pass through several functions; for example, an order passes from Sales through Production and Purchasing to Accounts Receivable and is processed further in the Production Controlling and Sales/Marketing. If each function manages its own data, the object relationship of processes will result in redundancy, because data that belong to one object are stored by several functions. Although this leads to increased physical storage requirements, the primary problem is one of logical data consistency, because the data definitions would not necessarily have to be consistent if each function defined its data according to its own requirements.

\section{Process: Order processing}

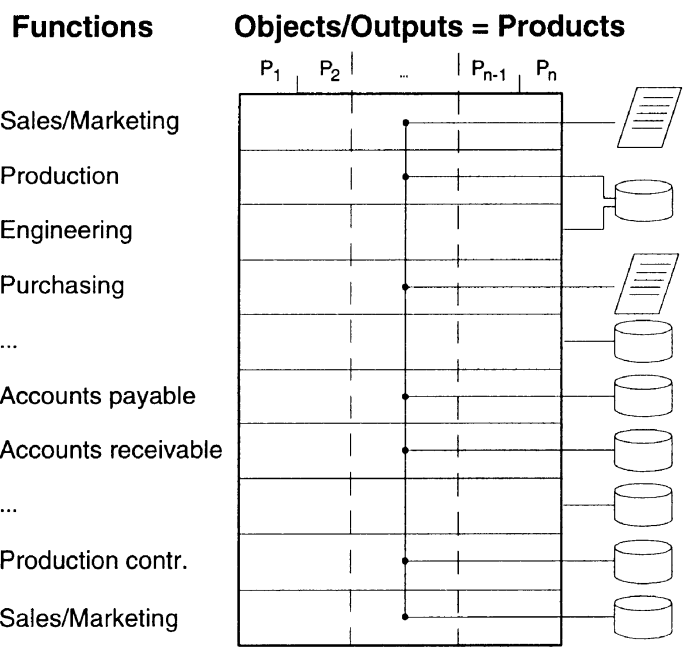

Figure 2 Reduction of complexity. 
As a result, functions tend to become integrated. This process is accompanied by dividing the complexity of an enterprise on the basis of other criteria, such as territories, locations or products. (Neis 1994, pp.98-101) In a purely object-oriented structure (vertical lines in Figure 2) as many functions as possible that are responsible for an object class are integrated within a group, which processes them. This makes it possible to decrease co-ordination and communication efforts between the individual processing functions. The most important disadvantage of this organisational form is that synergy effects that arise between the product groups are not exploitable to that extent.

This is the reason for hybrid organisational forms (thick line in Figure 3). Figure 3 gives an idea about it. The functions "supplier selection" and "terms" are performed centrally for all purchases and thus conform to a functional structure, while "planning," "ordering" and "checking and auditing invoices" are decentralised according to object-oriented structural criteria. (Scheer 1994, p.26) The object-oriented units can plan and order the components tailored to their special needs quickly and in a process-oriented manner, while the central functions "supplier selection" and "terms" reflect the synergy effects of the overall company vis-àvis the suppliers.

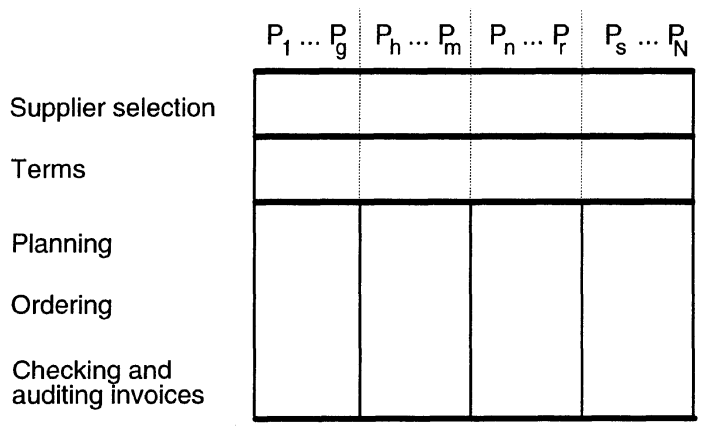

Figure 3 Hybrid organisational structure.

\section{CONCEPTION OF THE PLANNING CENTRE}

A comprehensive structure which consequently bases on these hybrid forms is called "networked decentralisation", because independently operating organisational units are supported that are both decentralised and networked with each other. (Scheer 1994, p.585) Operatively, the processes are handled in the decentralised units. The relationships between these decentralised units are treated at the superordinate co-ordination level. As a rule, these problems are not as closely linked in terms of time as the processes within the process-oriented organisational unit. Further planning units can be formed that encompass several coordination units. The planning functions can also be co-ordinated at a superordinate level.

There are already existing approaches of hybrid organisational forms at the shop floor level. The respective organisational units are called leitstands or production islands (see Fig- 
ure 4). A leitstand is an autonomous production system which is usually controlled by a central system like a production planning and control system. (Scheer/Hars 1990, pp.377-380) A consequent use of hybrid organisational form leads to the conception of the planning centre.

A planning centre represents an organisational paradigm that pays special attention to the needs of human beings working in it. It is a permanent organisational unit consisting of a group of staff. This group is responsible for the execution of a wide range of closely linked planning, controlling and implementation functions. (Kruse/Scheer 1994) The planning centre is installed in non-producing areas like sales, materials management, research and development etc. The planning centre acts to a large extent autonomously. Once the centre is built one essential task is-besides the daily work-to organise the own structure and the personnel's further qualification.

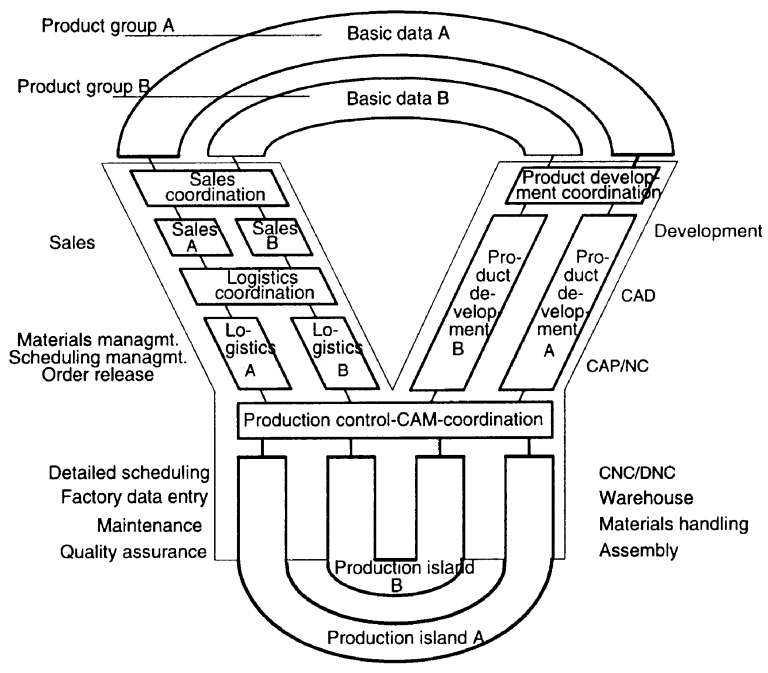

Figure 4 Planning centres.

Figure 4 illustrates the philosophy of the planning centre. Comprehensive processes are broken down into planning centres. Intra-actions within these centres are high and interactions between them low. Again there are the two dimensions of separation: processes and products. The result of re-engineering an enterprise may be an organisation, as shown in Figure 4, consisting of planning centres, two in each, for sales, logistics and product development. Special regard must be given to the co-ordination of planning centres to meet the requirements arisen by the fact that there are relationships between the planning centres. Therefore, planning centres have to be co-ordinated by central units. They also perform additional functions in order to take advantage of synergy effects like mentioned before.

Other types of planning centres may have to process, for example, a wider range of functions while there is a refined specialisation on objects. As an extreme case, you can think of one planning centre for each existing product processing the complete functional spectrum 
from marketing and order processing up to production and dispatch. All the planning centres are co-ordinated by a superordinated instance. This extreme idea is very close to the one of profit centres. (Keller 1993, pp.304-306)

Table 1 Characteristics and benefits of planning centres.

\begin{tabular}{|c|c|c|}
\hline Characteristics & Consequence & Benefit \\
\hline $\begin{array}{l}\text { autonomy (concerning determi- } \\
\text { nation of operative processes, } \\
\text { design of PC-internal organisa- } \\
\text { tion, right of disposal of resour- } \\
\text { ces) }\end{array}$ & $\begin{array}{l}\text { decision of those, which have } \\
\text { the best know-how } \\
\text { organisational weaknesses can } \\
\text { be eliminated immediately } \\
\text { when appearing } \\
\text { working environment is de- } \\
\text { signed according to the re- } \\
\text { quirements of staff } \\
\text { relocation of former manage- } \\
\text { ment tasks into the PC }\end{array}$ & $\begin{array}{l}\text { faster reactions, more } \\
\text { flexibility, higher satisfied } \\
\text { customers } \\
\text { "best" decision, "problem- } \\
\text { near solutions } \\
\text { continuous improvement } \\
\text { process } \\
\text { motivation, reduction of } \\
\text { absence times of staff } \\
\text { unburding of management, } \\
\text { reduction of number of } \\
\text { hierarchical levels }\end{array}$ \\
\hline process-orientation & $\begin{array}{l}\text { staff activities cover compre- } \\
\text { hensive functionality in proc- } \\
\text { ess chain }\end{array}$ & $\begin{array}{l}\text { less communication and co- } \\
\text { ordination effort, less } \\
\text { waiting and transferring } \\
\text { times }\end{array}$ \\
\hline overlapping qualification & $\begin{array}{l}\text { higher flexibility for employ- } \\
\text { ing staff }\end{array}$ & $\begin{array}{l}\text { higher process reliability, } \\
\text { higher use of capacity, eas- } \\
\text { ier disposition of staff }\end{array}$ \\
\hline primarily internal qualification & $\begin{array}{l}\text { steadily growing qualification } \\
\text { of staff with only low occupa- } \\
\text { tion of capacities }\end{array}$ & improving quality \\
\hline no superior in the group & $\begin{array}{l}\text { all members of PC have equal } \\
\text { rights }\end{array}$ & $\begin{array}{l}\text { higher motivation, innova- } \\
\text { tion, less absence }\end{array}$ \\
\hline $\begin{array}{l}\text { easy to survey location and } \\
\text { tasks }\end{array}$ & $\begin{array}{l}\text { communication and co-opera- } \\
\text { tion without formal pre-defi- } \\
\text { nition }\end{array}$ & $\begin{array}{l}\text { reduction of overhead } \\
\text { functions, less management } \\
\text { necessary }\end{array}$ \\
\hline multifarious work & working means learning & $\begin{array}{l}\text { continuous increasing of } \\
\text { staff qualification, motiva- } \\
\text { tion, absence }\end{array}$ \\
\hline
\end{tabular}

Table 1 gives an overview of the most important characteristics of planning centres and derived benefits from the perspective of the enterprise goals. 


\section{CONDUCTION OF RE-ENGINEERING}

In a first phase data about the current organisation of an enterprise has been collected and modelled by using the ARIS-Toolset of the IDS Prof. Scheer GmbH, Germany, which is based on the Architecture of Integrated Information Systems (ARIS) (Scheer 1992). The ARIS approach pre-defines four descriptive views and 3 life-cycle phases as shown in Figure 5 and thus, comprises 12 components. For each component a set of different suitable and integrated description methods is offered.

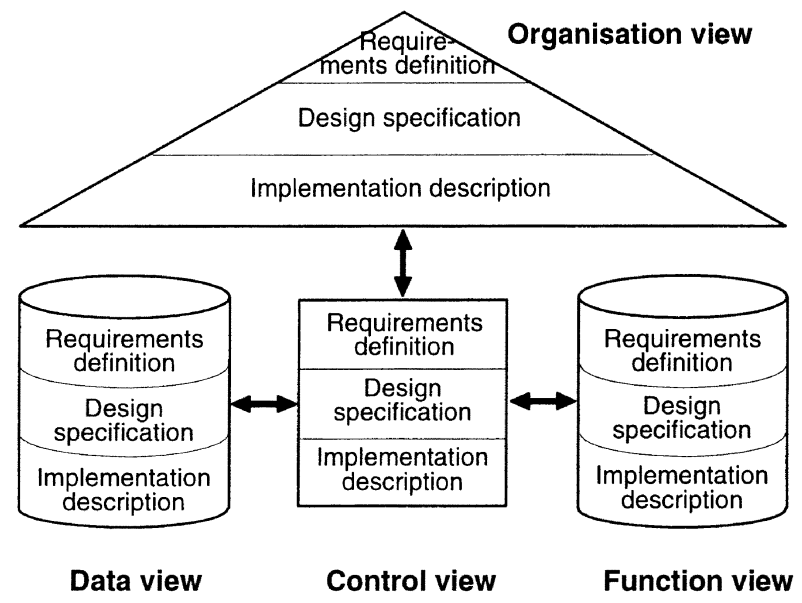

Figure 5 Architecture of Integrated Information Systems (ARIS).

The languages used for modelling the enterprise are entity-relationship models (ERM) for modelling the data view, hierarchy diagrams for the functions and organisations view and extended process chain diagrams (eEPK) (Keller, Nüttgens, Scheer 1992) for the process view. These models are analysed. Weaknesses like time-delays, unnecessary changes of information carriers, redundant execution of functions etc. are identified and eliminated. As a result, there are basic process structures. Parallel to this, principles and rules for distributing processes to organisational units are defined. Hierarchical and sequential completeness will be one of these principles, for example. This means, that functions are grouped together and processed by a planning centre, if they are directly sequential or if the output of a certain function represents the plan for conducting another one.

All the experiences about designing and implementing planning centres gained in the four partial projects are generalised by the IWi. As a result, reference models are defined that give generally accepted proposals (Hars 1993, p.15) for organising decentralised enterprise structures and their logical dependencies on important characteristics of the consortium's enterprises. The basic idea of a reference model is the re-usability of organisational knowhow. Several projects with industrial partners have shown that in every project there is a large amount of knowledge involved that could be re-used for other projects. Thus, knowledge that 
is required for successfully carrying out re-organisation projects, is divided into three categories: (Remme/Allweyer/Scheer 1994, p.234)

1. General knowledge which is independent from a certain company or a certain industrial branch. This includes general knowledge about organisation, business processes, and information technology.

2. Knowledge specific to important characteristics. This may be e.g. a certain industrial branch. This knowledge includes branch-specific requirements, typical processes and structures, common problems etc.

3. Knowledge specific to a certain company. This includes those characteristics of the company that are different from other companies of the same characteristics.

Instead of starting from scratch in every company, a re-organisation project based on reference models created in this project has already the knowledge covered by point 1 and 2 and only has to adapt the reference model to the company's very specific situation. It is therefore not necessary to "re-invent the wheel" in every project.

The ARIS-Toolset offers the functionality for storing reference models and their logical relationships to enterprise characteristics and for configuration of these reference models according to specific enterprise characteristics. Figure 6 describes the use of ARIS-Toolset and reference models. A certain company records models of the current organisation and a list of relevant characteristics has to be filled in. From this information which is based on the reference models and the logical rules, first proposals for the planning centre target specification, for the re-engineering process and for necessary staff qualification are configured automatically. Usually, these models have to be adapted to very individual characteristics of the enterprise, which cannot be covered by reference models.

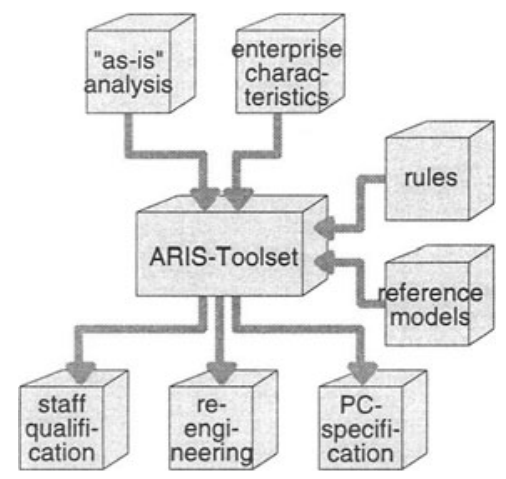

Figure 6 EDP-support of re-
engineering.

\section{FINAL STATEMENT}

Often, re-engineering projects fail because they are single-focused. The approach, presented here, focuses on organisation, human resources, and information and communication technol- 
ogy. All of these aspects are of equal importance. Re-engineering has to balance these to achieve an "organisational fit". The storing of experiences in tools makes re-engineering knowledge automaticable, and what's more important: transportable.

\section{REFERENCES}

Flood, R.L., Jackson M.C.: Creative Problem Solving - Total Systems Intervention, Chichester 1991.

Grossmann, C.: Komplexitätsbewältigung im Management, Anleitungen, integrierte Methodik und Anwendungsbeispiele, Diss. St. Gallen 1992.

Hars, A.: Referenzdatenmodelle: Grundlagen effizienter Datenmodellierung, Wiesbaden 1994.

Keller, Informationsmanagement in objektorientierten Organisationsstrukturen, Wiesbaden 1993.

Keller, G.; Nüttgens, M.; Scheer, A.-W.: Semantische Prozeßmodellierung auf der Grundlage "Ereignisgesteuerter Prozeßketten (EPK)", in: Scheer, A.-W. (eds.): Veröffentlichungen des Instituts für Wirtschaftsinformatik, Heft 89, Saarbrücken 1992.

Kruse, C.; Scheer, A.-W.: Dezentrale Prozeßkoordination in Planungsinseln, in: Information Management, 9(1994)3, S.6-11.

Neis, B.: Vernetzte administrative Inseln, Prozeßorientierte Organisationsformen zur Restrukturierung der Ablauf- und Aufbauorganisation, Diss. Saarbrücken 1994.

Remme, M.; Allweyer, T.; Scheer, A.-W.: Implementing Organizational Structures in Process Industry Supported by Tool-Based Reference Models, in: Boucher, Elsayed, Jafari (eds.): Computer Integrated Manufacturing in Process Industries, Proceedings of the CIMPRO \#94 Conference, East Brunswick NJ, 25.-26. April 1994, S. 233-247.

Scheer, A.-W.; Hars, A.: The Leitstand - A New Tool for Decentral Production Control, in: Fandel, G.; Zäpfel, G. (eds.): Modern Production Concepts, Theory and Application, Proceedings of an International Conference, Fernuniversität Hagen, August 20-24, 1990, Berlin et al. 1991, pp.370-385.

Scheer, A.-W.: Business Process Engineering, Reference Models for Industrial Enterprises, 2nd ed., Berlin et al. 1994.

Scheer, A.-W.: Architecture of Integrated Information Systems, Foundations of EnterpriseModelling, Berlin et al. 1992.

\section{BIOGRAPHY}

Dipl.-Kfm. Markus Remme has finished his studies of business administration in 1992 and is now working as a scientific assistant at the Institut für Wirtschaftsinformatik at the University of the Saarland, Germany.

Prof. Dr. August-Wilhelm Scheer is director of the Institut für Wirtschaftsinformatik at the University of the Saarland, Germany, and has established the CIM Technology Transfer Centre in Saarbrücken. He is honorary professor at the University of Vienna. Prof. Scheer is the editor of various serial books, journals and the author of more than 300 essays and 20 books. 